\title{
International Reserves, Current Account Imbalance and Short Term External Debt: A Comparative Study
}

\author{
Eliza Nor (Corresponding author) \\ School of Management, Universiti Sains Malaysia, 11800 USM, Penang, Malaysia \\ E-mail: eliza.nor@usm.my
}

M. Azali

Department of Economics, Faculty of Economics and Management

University Putra Malaysia, 43400 UPM, Serdang, Selangor, Malaysia

E-mail: azali@econ.upm.edu.my

Siong-Hook Law

Department of Economics, Faculty of Economics and Management

University Putra Malaysia, 43400 UPM, Serdang, Selangor, Malaysia

E-mail: lawsh@econ.upm.edu.my

Received: January 22, 2011

Accepted: February 12, 2011

doi:10.5539/ijef.v3n4p83

\begin{abstract}
This paper examines the behavior of international reserve holdings in East Asia, ASEAN5, and non-ASEAN countries during the period 1970-2005 using panel cointegration and FMOLS. The panel cointegration tests find the existence of long run relationship between international reserve holdings and its determinants. The panel group FMOLS results indicate that current account balance is statistically significant and exert a positive impact on international reserve holdings in East Asia, ASEAN5 and non-ASEAN countries while short term external debt shows a positive and negative impact on international reserve holdings in ASEAN5 and non-ASEAN countries, respectively.
\end{abstract}

Keywords: International reserves, Current account imbalance, Short term external debt, East Asia

\section{Introduction}

East Asian economies have been holding high level of international reserves since the 1997 East Asian financial crisis. Among the East Asian countries, China, Japan, Hong Kong, Korea, Malaysia, Taiwan, and Singapore are ranked among the top reserve holders. Even though reserves can provide liquidity and returns, there are several implications associated with high reserve holding. High reserve holdings in these countries in recent years reflect the prudence in their economic policies, high growth prospect, and surplus in their trade accounts. At the same time, high reserves are associated with the global external payments imbalances (World Bank, 2005).

The present paper analyzes the behavior of international reserve holdings in three groups of East Asian countries namely East Asia (Indonesia, China, Japan, Korea, Malaysia, the Philippines, Singapore, Taiwan, and Thailand), ASEAN5 (Indonesia, Malaysia, the Philippines, Singapore, and Thailand), and non-ASEAN countries (China, Japan, Korea, and Taiwan) using panel cointegration and Fully Modified Ordinary Least Squares (FMOLS). The study includes Indonesia, the Philippines, and Thailand because, like the rest of the countries, these ASEAN countries have also increased their international reserve holdings after the crisis.

Previous studies on international reserve holdings using pooled cross section and time series data have analyzed the behavior of international reserve holdings using data from developed countries (for instance, Bahmani-Oskooee, 1984, 1985; Edwards, 1984b; Flood \& Marion, 2002; Bahmani-Oskooee \& Brown, 2004) and developing countries (for instance, Iyoha, 1976; Edwards, 1984a, 1985; Aizenman \& Marion, 2003; Mendoza, 2004; Zhou, 2005; Ra, 2006). Studies that compare the behavior of international reserve holdings for both developed and developing countries include Frenkel (1980), Bahmani-Oskooee (1987), Lane and Burke (2001), Choi and Beak 
(2004), Aizenman and Lee (2005), and Choi, Sharma, and Sromqvist (2006). Gosselin and Parent (2005) and Cheung and Xing (2007) analyze international reserves in eight and ten Asian countries, respectively.

Nor, Azali and Law (2009) investigate the behavior of international reserve holdings in the context of nine East Asian countries using panel cointegration and FMOLS. The present paper extends the study by Nor, Azali and Law (2009) by comparing the determinants of international reserve holdings for three groups of East Asian countries; namely East Asia, ASEAN5 and non-ASEAN countries.

Even though studies by Gosselin and Parent (2005) and Cheung and Xing (2007) have analyzed the behavior of international reserve holdings in the Asian context, comparison between different groups of countries have not been made. Therefore, the study intends to fill up this gap in the literature. The present study also differs from previous studies in a way that it allows comparison among the determinants of international reserve holdings among the East Asia, ASEAN5, and the non-ASEAN countries. The ASEAN countries consist of countries that were seriously hit by the 1997 Asian crisis. On the other hand, the majority of non-ASEAN countries were not badly affected by the crisis (except Korea). By incorporating two different explanatory variables namely export volatility and short term external debt, the study intends to assess the precautionary motive of these countries in holding international reserves. In other words, the study intends to answer the following question: Do the ASEAN5 and the non-ASEAN countries hold high international reserves in order to meet the precautionary motive against export volatility and short term capital flow reversals?

The remainder of this paper is organized as follows. Section Two presents the trend in international reserve holdings in East Asia, ASEAN5, and non-ASEAN countries. Section Three summarizes the methodology and data to be employed in this study. The major findings are presented in Section Four. The last section concludes the paper.

\section{Trends in international reserve holdings}

This section discusses the trends in international reserve holdings in East Asia, ASEAN5, and the non-ASEAN countries. Figure 1 presents the trends in international reserve holdings in billion US dollars for the three groups of East Asian countries. These groups of countries had increased their international reserves holding especially after the 1997 financial crisis. East Asia shows the highest holdings of international reserves followed by the non-ASEAN countries. This is not surprising since East Asia consists of all the nine East Asian countries with high international reserve holdings. The total amount of reserves held in the non-ASEAN countries is very close to the total reserves held in East Asia because the former group consists of China and Japan, the top two reserve holders in the world.

\section{Methodology and data}

This section begins with a brief discussion on the model of international reserve holdings to be applied in this study. The discussion will then proceeds with the methodology to be used in this study. Three types of tests will be carried out. The first test is the panel unit root test. This test will be performed in order to test the order of integration of the variables. The second test is the panel cointegration test which will allow us to detect the existence of long run relationship between international reserves and its determinants. The final test is the Fully Modified Ordinary Least Squares (FMOLS). FMOLS will present the elasticity of each of the variables and the direction of their impact on international reserves.

\subsection{Model of international reserve holdings}

The basic model of international reserve holdings for this study is based on the theory proposed by Frenkel (1974a) where international reserve holding is a function of a scale variable, propensity to import, and the variability measure. The scale variable represents the volume of international transactions. Therefore, the relationship between the scale variable and international reserve holdings is expected to be positive. Propensity to import can have a positive or negative impact on international reserve holdings. If the relationship is positive, the variable acts as a proxy for openness of an economy (Frenkel, 1974b). Otherwise, it acts as marginal cost of adjustment (Heller, 1966). The variability measure is expected to have a positive relationship with international reserve holdings given the role of reserves play as a buffer stock in dealing with the fluctuations in international transactions (Frenkel \& Jovanovic, 1981).

We extend the basic model by incorporating two additional variables: current account balance and short term external debt. Current account balance is included in the model to take into account the surge in current account surplus of the nine East Asian countries, especially after the 1997-98 financial crisis. In addition, the relationship between international reserves and current account in East Asia has been widely discussed recently (see among others, Genberg, McCauley, Park, \& Persaud, 2005; Tanuichi, 2006; Eichengreen \& Park, 2006; International Relations Committee Task Force, 2006), indicating the growing importance of the issue. However, there is limited 
empirical evidence to support this relationship. The relationship between current account balance and international reserve holdings for this study is established based on the theories presented by Dunn and Mutti (2000) and Taniuchi (2006).

The study also incorporates short term external debt as a determinant of international reserve holdings for East Asian countries. Recently, the importance of external debt in explaining international reserve holdings in emerging market economies has been widely discussed in both the empirical and theoretical literature related to international reserves. Recent papers that discuss the relationship between external debt and international reserves include Garcia (1999), Aizenman and Marion (2003, 2004), Aizenman, Lee, \& Rhee (2004, 2007), Jeanne and Ranciere (2006), Jeanne (2007), and Alfaro and Kanczuk (2007). The incorporation of this variable as explanatory variable would reflect the importance of the precautionary motive for holding reserves in East Asia after the 1997-98 financial crisis as highlighted by the recent theories on international reserve holdings. Both current account balance and short term external debt can exert either a positive or negative impact on international reserve holdings.

Based on the theories summarized above, the model of international reserve holdings to be estimated in this study is as follows:

$$
\ln R_{i t}=\alpha_{i}+\theta_{i} \tau+\delta_{11} \ln Y C_{i t}+\delta_{12} \ln P I M_{i t}+\delta_{13} \ln X P V_{i t}+\delta_{14} \ln C A_{i t}+\delta_{15} \ln S T D_{i t}+\varepsilon_{i t}
$$

where $\operatorname{lnR}$ is the ratio of international reserves to GDP; $\ln Y C$ is the real GDP per capita (scale variable); $\ln P I M$ is the average propensity to import (imports/GDP); $\ln X P V$ is the variability in real export receipts; lnCA is the ratio of current account balance to GDP; $\operatorname{lnSTD}$ is the ratio of short term external debt to GDP; $\tau$ is the time trend and $\varepsilon$ is the error term. All variables are expressed in logarithms.

\subsection{Panel unit root tests}

The panel unit root tests to be employed include the Levin, Lin, and Chu (LLC) and the Im, Pesaran, and Shin (IPS) tests.

\subsubsection{Levin, Lin, and Chu (LLC) test}

Consider the following regressions:

(a) $\Delta Y_{i t}=\lambda Y_{i t-1}+\varepsilon_{i t}$

(b) $\Delta Y_{i t}=\alpha_{0 i}+\lambda Y_{i t-1}+\varepsilon_{i t}$

$$
\text { (c) } \Delta Y_{i t}=\alpha_{0 i}+\alpha_{1 i} \tau+\lambda Y_{i t-1}+\varepsilon_{i t}, \quad-2<\lambda \leq 0 \text { for } i=1, \ldots, N \text {. }
$$

where $\tau$ is the trend term.

The error term is assumed to be uncorrelated and is given by:

$$
\varepsilon_{i t}=\sum_{j=1}^{\infty} \phi_{i j} \varepsilon_{i t-j}+\mu_{i t}
$$

The following hypotheses will be tested for models 1,2 , and 3 :

Model (1):

$\mathrm{H}_{0}: \lambda=0$

$\mathrm{H}_{\mathrm{a}}: \lambda<0$

Model (2):

$\mathrm{H}_{0}: \lambda=0$ and $\alpha_{0 i}=0$

$\mathrm{H}_{\mathrm{a}}: \lambda<0$ and $\alpha_{0 i} \in R$

Model (3):

$\mathrm{H}_{0}: \lambda=0$ and $\alpha_{1 i}=0$

$\mathrm{H}_{\mathrm{a}}: \lambda<0$ and $\alpha_{1 i} \in R$

There are three steps to be followed in the panel unit tests proposed by Levin et al. (2002). The first step is to perform the following regression:

$$
\Delta Y_{i t}=\alpha_{v i} f_{v i=1}+\lambda_{i} Y_{i t-1}+\gamma_{i} \sum_{L=1}^{P_{i}} \phi_{i L} \Delta Y_{t-i}+\varepsilon_{t} \quad v=1,2,3
$$

In Step 2, we calculate the ratio of long-run to short-run standard deviations. The long run variance for Model 1 is given by:

$$
\hat{\sigma}_{Y i}^{2}=\frac{1}{T-1} \sum_{t=2}^{T} \Delta Y_{i t}^{2}+2 \sum_{L=1}^{\dddot{K}} W_{\bar{K} L}\left[\frac{1}{T-1} \sum_{t=2+L}^{T} \Delta Y_{i t} \Delta Y_{i t-L}\right]
$$


The ratio of long-run standard deviation to the standard deviation of the error term is $s_{i}=\sigma_{Y_{i}} / \sigma_{\varepsilon i}$ and the estimate of the above ratio is given by. $\hat{s}_{i}=\hat{\sigma}_{Y_{i}} / \hat{\sigma}_{\varepsilon i}$. The third step is to calculate the panel test statistics. $\hat{e}_{i t}=\lambda \eta_{i t-1}+\widetilde{\varepsilon}_{i t}$ is the error term estimated based on the pooled cross-section time series data. The total number of observations is $N \widetilde{T}$ where the average number of observations for each individual in the panel and the average lag order for each ADF regression are given by $\widetilde{T}=T-\bar{p}-1$ and $\bar{p} \equiv \frac{1}{N} \sum_{i=1}^{N} p_{i}$ respectively. The t-statistic to test the null of $\lambda=0$ is:

$$
t_{\lambda}=\frac{\hat{\lambda}}{\operatorname{STDEV}(\hat{\lambda})}
$$

where

$$
\begin{gathered}
\hat{\lambda}=\frac{\sum_{i=1}^{N} \sum_{t=2+p_{i}}^{T} \widetilde{\eta}_{i t-1} \widetilde{e}_{i t}}{\sum_{i=1}^{N} \sum_{t=2+p_{i}}^{T} \widetilde{\eta}_{i t-1}} \ldots \ldots \ldots . . . . \\
\operatorname{STDEV}(\hat{\lambda})=\hat{\sigma}_{\widetilde{\varepsilon}}\left[\sum_{i=1}^{N} \sum_{t=2+p_{i}}^{T} \widetilde{\eta}_{i t-1}^{2}\right]^{-1 / 2} \ldots \\
\hat{\sigma}_{\widetilde{\varepsilon}}^{2}=\left[\frac{1}{N \widetilde{T}} \sum_{i=1}^{N} \sum_{t=2+p_{i}}^{T}\left(\widetilde{e}_{i t}-\hat{\lambda} \widetilde{\eta}_{i t-1}\right)^{2}\right] . . .
\end{gathered}
$$

$t_{\lambda}$ calculated above can be applied for Model 1 since the t-statistic in Model 1 follows the normal distribution. On the other hand, the t-statistics for Models 2 and 3 deviate to negative infinity. Thus, the following adjusted t-statistic will be applied:

$$
t_{\lambda}^{*}=\frac{t_{\lambda}-N \widetilde{T} \hat{S}_{N} \hat{\sigma}_{\widetilde{\varepsilon}}^{-2} \operatorname{STDEV}(\hat{\lambda}) \mu_{m \widetilde{T}}}{\sigma_{m \widetilde{T}}^{*}}
$$

3.2.2 Im, Pesaran, and Shin (IPS) test

Im, Pesaran, and Shin (2003) propose a panel unit test based on the average of the Dickey-Fuller test statistics. The test allows for the presence of serial correlation. Consider the following regression:

$$
\begin{aligned}
Y_{i t} & =\left(1-\vartheta_{i}\right) \eta_{i}+\vartheta_{i} Y_{i, t-1}+e_{i t} \\
\Delta Y_{i t} & =\alpha_{1}+\lambda_{i} Y_{i, t-1}+e_{i t} \ldots \ldots
\end{aligned}
$$

where $\Delta Y_{i t}=Y_{i t}-Y_{i, t-1} ; \quad \alpha_{1}=\left(1-\vartheta_{i}\right) \eta_{i} ; \lambda_{i}=-\left(1-\vartheta_{i}\right)$. Below are the null and alternative hypotheses of a unit root:

$\mathrm{H}_{0}: \lambda_{i}=0, \quad$ for all $i$

$\mathrm{H}_{\mathrm{a}}: \lambda_{i}<0, \quad$ for $i=1,2, \ldots, N_{1}$

$\mathrm{H}_{\mathrm{a}}: \lambda_{i}=0, \quad$ for $i=N_{1}+1, \quad N_{1}+2, \ldots, N$

where $\lambda_{i}$ is allowed to differ across individuals. $T \rightarrow \infty$ and followed by $N \rightarrow \infty$. The t-bar statistic is defined as:

$$
\widetilde{t}=\frac{1}{N} \sum_{i=1}^{N} \widetilde{t}_{i T}
$$

where $\tilde{t}_{i T}$ is the individual t-statistic. By assuming that $T_{i}$ differs across individuals and $\widetilde{t}_{i T}$ is independently distributed across individual, the standardized t-bar statistic is:

$$
\tilde{t}_{\text {std }}=\frac{\sqrt{N}\left\{\tilde{t}-E\left(\widetilde{t}_{T}\right)\right\}}{\sqrt{\operatorname{Var}\left(\tilde{t}_{T}\right)}}
$$

where $\tilde{t}$ is as defined by (4.39), $E\left(\widetilde{t}_{T}\right)$ and $\operatorname{Var}\left(\tilde{t}_{T}\right)$ are the mean and variance of $\tilde{t}_{i T}$, respectively.

\subsection{Panel cointegration}

Pedroni (1997) develops seven test statistics for panel cointegration. Four of them are panel or within-dimension. These statistics are computed by adding up the numerator and denominator terms separately like the usual time 
series statistics. The second group of statistics is the group or between-dimension statistics. These statistics are computed by pooling the data along the between dimension of the panel. In the first step, the ratio that corresponds to the usual time series statistic is computed. Next, the standardized sum of the whole ratio is calculated for over the $N$ dimension of the panel. The seven statistics developed by Pedroni (1997) are presented below:

Panel $v$-statistic

$$
Z_{v}=T^{2} N^{3 / 2}\left(\sum_{i=1}^{N} \sum_{T=1}^{T} \widehat{L}_{11 i}^{-2} \widehat{\varepsilon}_{I t-1}^{2}\right)^{-1}
$$

Panel rho-statistic

$$
Z_{r h o}=T N^{1 / 2}\left(\sum_{i=1}^{N} \sum_{T=1}^{T} \widehat{L}_{11 i}^{-2} \widehat{\varepsilon}_{I t-1}^{2}\right)^{-1} \sum_{i=1}^{N} \sum_{T=1}^{T} \widehat{L}_{11 i}^{-2}\left(\widehat{\varepsilon}_{I t-1}^{2} \Delta \hat{\varepsilon}_{i t}-\lambda_{\hat{i}}\right)
$$

Panel pp-statistic

$$
Z_{p p}=\left(\widetilde{\sigma}_{N T}^{2} \sum_{i=1}^{N} \sum_{T=1}^{T} \widehat{L}_{11 i}^{-2} \widehat{\varepsilon}_{I t-1}^{2}\right)^{-1 / 2} \sum_{i=1}^{N} \sum_{T=1}^{T} \widehat{L}_{11 i}^{-2}\left(\widehat{\varepsilon}_{I t-1}^{2} \Delta \hat{\varepsilon}_{i t}-\lambda_{\hat{i}}\right)
$$

Panel adf-statistic:

$$
\left.Z_{\text {adf }}=\left(s_{N T}^{2} \sum_{i=1}^{N} \sum_{T=1}^{T} \widehat{L}_{11 i}^{-2} \widehat{\varepsilon}_{I t-1}^{* 2}\right)^{-1 / 2}\right)^{-1 / 2} \sum_{i=1}^{N} \sum_{T=1}^{T} \widehat{L}_{11 i}^{-2} \widehat{\varepsilon}_{I t-1}^{2} \Delta \hat{\varepsilon}_{i t}^{*} \ldots
$$

Group rho-statistic:

$$
\widetilde{Z}_{r h o}=T N^{-1 / 2} \sum_{i=1}^{N}\left(\sum_{t=1}^{T} \widehat{\varepsilon}_{I t-1}^{2}\right)^{-1} \sum_{t=1}^{T}\left(\widehat{\varepsilon}_{I t-1}^{2} \Delta \hat{\varepsilon}_{i t}-\lambda_{\bar{i}}\right) \ldots
$$

Group pp-statistic

$$
\widetilde{Z}_{p p}=N^{-1 / 2} \sum_{i=1}^{N}\left(\widehat{\sigma}_{i}^{2} \sum_{t=1}^{T} \widehat{\varepsilon}_{I t-1}^{2}\right)^{-1 / 2} \sum_{t=1}^{T}\left(\widehat{\varepsilon}_{I t-1}^{2} \Delta \hat{\varepsilon}_{i t}-\lambda_{\bar{i}}\right)
$$

Group adf-statistic

$$
\widetilde{Z}_{\text {adf }}=N^{-1 / 2} \sum_{i=1}^{N}\left(\sum_{t=1}^{T} \widehat{s}_{i}^{* 2} \varepsilon_{I t-1}^{*_{2}}\right)^{-1 / 2} \sum_{t=1}^{T}\left(\widehat{\varepsilon}_{I t-1}^{*} \Delta \hat{\varepsilon}_{i t}^{*}-\lambda_{\bar{i}}\right)
$$

where

$$
\begin{gathered}
\hat{\lambda}_{i}=\frac{1}{T} \sum_{s=1}^{k_{i}}\left(1-\frac{s}{k_{i}+1}\right) \sum_{t=s+1}^{T} \widehat{\mu}_{i t} \widehat{\mu}_{i t-s} ; \hat{s}_{i}^{2} \equiv \frac{1}{T} \sum_{t=1}^{T} \widehat{\mu}_{i t}^{2} ; \hat{\sigma}_{i}^{2}=\hat{s}_{i}^{2}+2 \hat{\lambda}_{i} ; \quad \widetilde{\sigma}_{N T}^{2} \equiv \frac{1}{N} \sum_{i=1}^{N} \hat{L}_{11 i}^{-2} \hat{\sigma}_{i}^{2} \\
\widehat{s}_{i}^{* 2} \equiv \frac{1}{t} \sum_{t=1}^{T} \widehat{\mu}_{i t}^{* 2} ; \widehat{s}_{N T}^{* 2} \equiv \frac{1}{N} \sum_{i=1}^{N} \hat{s}_{i}^{* 2} ; \text { and } \hat{L}_{11 i}^{2}=\frac{1}{T} \sum_{i=1 i t}^{T} \hat{n}_{i t}^{2}+\frac{2}{T} \sum_{s=1}^{k_{i}}\left(1-\frac{s}{k_{i}+1}\right) \sum_{t=s+1}^{T} \hat{n}_{i t} n_{i t-s} .
\end{gathered}
$$

\subsection{Fully modified ordinary least squares (FMOLS)}

The FMOLS methodology presented in this section has been developed by Pedroni $(1996,2004)$. Consider the following regression

$$
Y_{i t}=\alpha_{i}+\beta x_{i t}+\varepsilon_{i t}
$$

$x_{i t}=x_{i t-1}+e_{i t}$

$$
\text { or } \quad e_{i t}=x_{i t}-x_{i t-1}=\Delta x_{i t}
$$

where the vector of errors is stationary with asymptotic covariance matrix $\Omega_{\mathrm{i}} . \Omega_{\mathrm{i}}$ is defined below:

$$
\Omega_{i}=\left[\begin{array}{ll}
\Omega_{11 i} & \Omega_{21 i}^{\prime} \\
\Omega_{21 i} & \Omega_{22 i}
\end{array}\right] \text {.......... }
$$

where $\Omega_{11 i}$ is a scalar of long run variance of the errors $\varepsilon_{i t} ; \Omega_{22 i}$ is $\mathrm{m} \mathrm{x} \mathrm{m} \mathrm{vector} \mathrm{of} \mathrm{long} \mathrm{run} \mathrm{covariance} \mathrm{among}$ the errors $e_{i t} ; \Omega_{21 i}$ is $\mathrm{m} \times 1$ vector of long run covariance between $\varepsilon_{i t}$ and $e_{i t} . \Omega_{i}$ differs across individual members in the panel and it can be defined as

$$
\Omega_{i}=\Omega_{i}^{c}+\Theta_{i}+\Theta_{i}
$$

where $\Omega_{i}^{c}$ is the contemporaneous covariance and $\Theta_{i}$ is the weighted sum of covariances. The FMOLS estimator is 


$$
\beta_{F M O L S}-\beta=\left(\sum_{i=1}^{n} \hat{R}_{22 i}^{-2} \sum_{t=1}^{T}\left(x_{i t}-\bar{x}_{i t}\right)^{2}\right)^{-1} \sum_{i=1}^{N} \hat{R}_{11 i}^{-2} \hat{R}_{22 i}^{-2}\left(\sum_{t=1}^{T}\left(x_{i t}-\bar{x}_{i}\right) m_{i t}^{*}-T \hat{\lambda}_{i}\right)
$$

where $m_{i t}^{*}=m_{i t}-\frac{\hat{R}_{21 i}}{\hat{R}_{22 i}} \Delta x_{i t}$ and $\hat{\lambda}_{i} \equiv \hat{\Theta}_{21 i}+\hat{\Omega}_{21 i}^{c}-\frac{\hat{R}_{21 i}}{\hat{R}_{22 i}}\left(\hat{\Theta}_{21 i}+\hat{\Omega}_{21 i}^{c}\right) . \beta_{F M O L S}$ converges to the true value at the rate of $T(N)^{1 / 2}$ and its distribution is presented below:

$$
T \sqrt{N}\left(\beta_{F M O L S}^{*}-\beta\right) \rightarrow N(0, v)
$$

where $v=\begin{aligned} & 2 \text { iff } \bar{x}_{i}=\bar{y}_{i}=0 \\ & 6 \text { else }\end{aligned}$ as $T \rightarrow \infty$ and $N \rightarrow \infty$. Below is the pooled panel FMOLS statistic

$$
t_{F M O L S}=\left(\beta_{F M O L S}-\beta\right)\left(\sum_{i=1}^{n} \hat{R}_{22 i}^{-2} \sum_{t=1}^{T}\left(x_{i t}-\bar{x}_{i}\right)^{2}\right)^{-1 / 2} \rightarrow N(0,1)
$$

$t_{F M O L S}$ is standard normal as $T \rightarrow \infty$ and $N \rightarrow \infty$.

\subsection{Data}

This study utilizes annual data covering the period of 1970-2005. Export volatility is measured by the standard deviation of real export receipts (Edison, 2003). Real export receipts were calculated as the nominal exports deflated by the respective countries' consumer price index. All absolute values are expressed in million US dollars. Sources of data are summarized in Table 1.

\section{Discussion of findings}

Prior to performing panel cointegration tests, we performed panel unit root test using Im, Pesaran, and Shin (IPS) (2003) and Levin, Lin, and Chu (LLC) (2002) procedures. The results of IPS and LLC indicate that all variables are I(1) or stationary at first difference (Table 2). Therefore, we proceed with panel cointegration tests. The results of panel cointegration are presented in Table 3.

Table 4 presents the results of FMOLS for East Asia, ASEAN5 and the non-ASEAN countries. GDP per capita $(\operatorname{lnYC})$ appears with a positive sign and significant in these groups of countries implying that the higher the volume of international transactions, the higher the international reserve holdings. Propensity to import (lnPIM) and export volatility (lnXPV) also appear with positive coefficients but significant only in the first two groups of countries. Positive coefficient of InPIM indicates that an economy with high degree of openness would hold high international reserves. A positive relationship between $\operatorname{lnXPV}$ and $\operatorname{lnR}$ in East Asia and ASEAN5 suggests that these groups of countries are concerned with the volatility in export receipts and thereby would increase their international reserve holdings as their export volatility increases.

Current account balance (lnCA) appears with a positive coefficient in East Asia, ASEAN5, and non-ASEAN countries. The result implies that current account surplus leads to high international reserve accumulation in these groups of countries.

Short-term external debt (lnSTD) is inversely related to international reserve holdings in the ASEAN5 countries, indicating the role of short-term external debt as a substitute for international reserves. This result is consistent with the findings by Lane and Burke (2001) who find an inverse relationship between international reserve holdings and short term external debt for emerging economies.

Unlike in the ASEAN5 countries, short term external debt shows a positive relationship with international reserve holdings in the non-ASEAN countries. This result suggests that short term external debt is a complement for international reserves. In other words, a rise in short term external debt supports the precautionary motive for holding reserves. Such precautionary actions taken by the non-ASEAN countries may explain the ability of these countries to weather the adverse impact of short term capital flow reversals during the 1997 crisis.

The insignificance impact of short term debt in East Asia may due to the negative and positive impact of short term debt in ASEAN5 and the non-ASEAN countries, respectively. The impact is cancelled out for East Asia since this group consists of the combination of ASEAN5 and the non-ASEAN countries.

\section{Conclusion and policy implications}

This paper analyzes the determinants of international reserve holdings in three groups of East Asian countries namely East Asia, ASEAN5, and the non-ASEAN countries for the period 1970-2005 using panel cointegration tests developed by Pedroni $(1997,2004)$ and FMOLS (Pedroni, 1996, 2000). The empirical results suggest the existence 
of long run relationship between international reserve holdings and its determinants (real GDP per capita, propensity to import, real export volatility, the ratio of current account balance to GDP, and the ratio of short term external debt to GDP).

The following conclusions can be drawn from the findings. First, current account balance is positive and significant in East Asia, ASEAN5 and non-ASEAN countries. This implies that a rise in current account surplus leads to international reserve accumulation in these groups of countries. This is because during the period with current account surplus, monetary authorities intervene in foreign exchange market through the purchase of foreign currencies and the sale of domestic currency (Dunn \& Mutti, 2000; Taniuchi, 2006). Even though current account surplus is the excess savings by the private sector, the private sector has limited means to transform their savings into investment abroad since most of the East Asian countries are still developing their financial markets and systems. As a result, the public sector converts the savings into investment in foreign currency assets in the form of the build up of international reserves (Genberg et al., 2005, p. 13).

Second, the ASEAN5 and the non-ASEAN countries show different motive in holding international reserves. While short term external debt is a complement for international reserves in the non-ASEAN countries, the variable acts as a substitute for international reserves in the ASEAN5 economies. This result suggests that the non-ASEAN countries take a precautionary action by holding international reserves against short term capital flow reversals. On the other hand, in ASEAN5, short term debt is used to finance international transactions. The ASEAN5 economies also hold international reserves in order to protect against volatility in export receipts. In summary, both the ASEAN5 and the non-ASEAN countries show some differences in their motive of holding international reserves.

\section{Acknowledgement}

We would like to express our sincere appreciation to the participants at the $8^{\text {th }}$ AAM Conference and anonymous referees for their helpful comments and suggestions on the earlier version of the paper.

\section{References}

Aizenman, J., \& Lee J. (2005). International reserves: precautionary versus mercantilist views, theory and evidence. NBER Working Paper No. 11366.

Aizenman, J., Lee, Y., \& Rhee, Y. (2004). International reserve management and capital mobility in a volatile world: policy considerations and a case study of Korea. NBER Working Paper No. 10534.

Aizenman, J., Lee, Y., \& Rhee, Y. (2007). International reserve management and capital mobility in a volatile world: Policy considerations and a case study of Korea. Journal of Japanese and International Economies. 21(1), 1-15. doi:10.1016/j.jjie.2005.12.001, http://dx.doi.org/10.1016/j.jjie.2005.12.001

Aizenman, J, \& Marion, N. (2003). The high demand for international reserves in the Far East: what is going on? Journal of the Japanese and International Economies. 17(3), 370-400. doi:10.1016/S0889-1583(03)00008-X, http://dx.doi.org/10.1016/S0889-1583(03)00008-X

Aizenman, J, \& Marion, N. (2004). International reserve holdings with sovereign risk and costly tax collection. Economic Journal. 114(497), 569-591. doi:10.1111/j.1468-0297.2004.00232.x, http://dx.doi.org/10.1111/j.1468-0297.2004.00232.x

Alfaro, L. \& Kanczuk, F. (2007). Optimal reserves management and sovereign debt. NBER Working Paper No. 13216. Asian Development Bank. (various issues). Key Indicators of Developing Asian and Pacific Countries. Manila: Asian Development Bank.

Bahmani-Oskooee, M. (1984). Gold price as another determinants of demand for international reserves. Journal of Economic Studies. 11(4), 23-32. doi:10.1108/eb002587, http://dx.doi.org/10.1108/eb002587

Bahmani-Oskooee, M. (1985). Demand for and supply of international reserves: a simultaneous approach. Journal of Post Keynesian Economics. 7(4), 493-503.

Bahmani-Oskooee, M. (1987). Demand for international reserves: corrections for serial correlation and heteroscedasticity. Applied Economics. 19(5), 609-618. doi:10.1080/00036848700000027, http://dx.doi.org/10.1080/00036848700000027

Bahmani-Oskooee, M., \& Brown, F. (2004). Kalman filter approach to estimate the demand for international reserves. Applied Economics. 36(15), 1655-1668. doi:10.1080/0003684042000218543, http://dx.doi.org/10.1080/0003684042000218543

Bank of Japan (1994). Balance of payments: Before the revision (1946-1994). International Department of Research and Statistics, Bank of Japan. [Online] Available: http://www.boj.or.jp/en/ 
Cheung, Y.W., \& Xing, W.Q. (2007). Hoarding of international reserves: Mrs Machlup's wardrobe and the Joneses. CESifo Working Paper No. 2065.

Choi, C., \& Beak S.G. (2004). Exchange rate regime and international reserves. Myongji University and Hongik University Working Paper.

Choi, W.G., Sharma, S., \& Stromqvist, M. (2006). Capital flows, financial integration, and international reserve holdings: the recent experience of emerging markets and advanced countries. International Monetary Fund Working Paper.

Directorate General of Budget, Accounting, and Statistics, Republic of Taiwan (2008). [Online] Available: http:www.dgbas.gov.tw/public/data/dgbas03/bs3/english/cpiidx.xls.

Dunn, R.M., \& Mutti, J.H. (2000). International Economics (5th Ed.). London: Routledge.

Edison, H. (2003). Are foreign exchange reserves in Asia too high? In International Monetary Fund, World economic outlook (pp. 78-92). Washington D.C.: International Monetary Fund.

Eichengreen, B., \& Park, Y.C. (2006, July). Global imbalances and emerging markets. Paper presented at the Conference on European and Asian Perspectives on Global Imbalances, Beijing.

Edwards, S. (1984a). The demand for international reserves and monetary equilibrium: some evidence from developing countries. Review of Economics and Statistics. 66(3), 495-500. doi:10.2307/1925009, http://dx.doi.org/10.2307/1925009

Edwards, S. (1984b). The role of international reserves and foreign debt in the external adjustment process. In J. Muns (Eds.), Adjustment, conditionality, and international financing (pp. 143-169). Washington D.C: International Monetary Fund.

Edwards, S. (1985). On the interest-rate elasticity of the demand for international reserves: some evidence from developing countries. Journal of International Money and Finance. 4(2), 287-295. doi:10.1016/0261-5606(85)90049-X, http://dx.doi.org/10.1016/0261-5606(85)90049-X

Flood, R., \& Marion, N. (2002). Holding international reserves in an era of high capital mobility. IMF Working Paper No. 02/62

Frenkel, J. (1974a). The demand for international reserves by developed and less-developed countries. Economica. 41(161), 14-24. doi:10.2307/2553419, http://dx.doi.org/10.2307/2553419

Frenkel, J. (1974b). Openness and the demand for international reserves. In: R.Z. Aliber (Ed.), National monetary policies and international financial system. Chicago: University of Chicago.

Frenkel, J. (1980). International reserves under pegged exchange rates and managed float. Journal of Monetary Economics. 6(2), 295-302. doi:10.1016/0304-3932(80)90034-3, http://dx.doi.org/10.1016/0304-3932(80)90034-3

Frenkel, J., \& Jovanovic, B. (1981). Optimal international reserves: a stochastic framework. Economic Journal. 91(362), 507-514. doi:10.2307/2232599, http://dx.doi.org/10.2307/2232599

Garcia, P. (1999). Demand for reserves under international capital mobility. Central Bank of Chile Working Papers No. 58.

Genberg, H., McCauley, R., Park, Y. C., \& Persuad, A. (2005). Official reserves and currency management in Asia: myth, reality, and the future. Geneva Report on the World Economy No. 7, Geneva: International Center for Monetary and Banking Studies.

Gosselin, M., \& Parent, N. (2005). An empirical analysis of foreign exchange reserves in emerging Asia. Bank of Canada Working Paper No. 2005-38.

Groningen Growth and Development Center and the Conference Board (2007). Total Economy Database. [Online] Available: http://www.ggdc.net

Heller, H.R. (1966). Optimal international reserves. Economic Journal. 76, 296-311. doi:10.2307/2229716, http://dx.doi.org/10.2307/2229716

Im, K.S., Pesaran, M.H., \& Shin, Y. (2003). Testing for unit roots in heterogeneous panels. Journal of Econometrics. 115(1), 53-74. doi:10.1016/S0304-4076(03)00092-7, http://dx.doi.org/10.1016/S0304-4076(03)00092-7

International Relations Committee Task Force (2006). The accumulation of foreign reserves. European Central Bank Occasional Paper Series No. 43.

International Monetary Fund (2006). World Economic Outlook. Washington D.C.: International Monetary Fund. 
International Monetary Fund (various issues). International Financial Statistics. Washington D.C.: International Monetary Fund.

Iyoha, M. (1976). Demand for international reserves in less developed countries: a distributed lag specification. Review of Economics and Statistics. 58(3): 351-355. doi:10.2307/1924957, http://dx.doi.org/10.2307/1924957

Jeanne, O., \& Ranciere, R. (2006). The optimal level of international reserves for emerging market countries: formulas and applications. IMF Working Paper.

Jeanne, O. (2007). International reserves in emerging market countries: too much of a good thing? Brookings Papers on Economic Activity. 38(1), 1-56. doi:10.1353/eca.2007.0013, http://dx.doi.org/10.1353/eca.2007.0013

Lane, P.R. \& Burke, D. (2001). The empirics of foreign reserves. Open Economies Review. 12(4), 423-434. doi:10.1023/A:1017939118781, http://dx.doi.org/10.1023/A:1017939118781

Lane, P.R., \& Milesi-Ferretti, G.M. (2009). The external wealth of nations Mark II: revised and extended estimates of foreign assets and liabilities, 1970-2004. IMF Working Paper No. 06/69.

Levin, A., Lin, C.F., \& Chu, C.S.J. (2002). Unit root tests in panel data: asymptotic and finite-sample properties. Journal of Econometrics. 108(1), 1-24. doi:10.1016/S0304-4076(01)00098-7, http://dx.doi.org/10.1016/S0304-4076(01)00098-7

Mendoza, R.U. (2004). International reserve-holding in the developing world: self insurance in a crisis-prone era? Emerging Markets Review. 5(1), 61-82. doi:10.1016/j.ememar.2003.12.003, http://dx.doi.org/10.1016/j.ememar.2003.12.003

Newey W. K. \& West, K.D. (1987). A simple, positive semi-definite, heteroskedasticity and autocorrelation consistent covariance matrix. Econometrica, 55(3), 703-708. doi:10.2307/1913610, http://dx.doi.org/10.2307/1913610

Nor, E., Azali, M. \& Law, S. H. (2009). Demand for international reserves: evidence from East Asia. American Journal of Finance and Accounting, 1(3), 297-310. doi:10.1504/AJFA.2009.026485, http://dx.doi.org/10.1504/AJFA.2009.026485

Taniuchi, M. (2006). Global imbalances and Asian economies. JBICI Review No. 14.

Pedroni, P. (1999). Critical values for cointegration tests in heterogeneous panels with multiple regressors. Oxford Bulletin of Economics and Statistics. 61(S1), 653-70. doi:10.1111/1468-0084.61.s1.14, http://dx.doi.org/10.1111/1468-0084.61.s1.14,

Pedroni, P. (1996). Fully modified OLS for heterogeneous cointegrated panels and the case of purchasing power parity. Indiana University Working Papers in Economics No. 96-020.

Pedroni, P. (1997). Panel cointegration, asymptotic and finite sample properties of pooled time series tests with an application to the PPP hypothesis: new results. Indiana University Working Paper.

Pedroni, P. (2000). Fully modified OLS for heterogeneous cointegrated panels. Advances in Econometrics. 15, 93-130. doi:10.1016/S0731-9053(00)15004-2, http://dx.doi.org/10.1016/S0731-9053(00)15004-2

Pedroni, P. (2004). Panel cointegration, asymptotic and finite sample properties of pooled time series tests with an application to the PPP hypothesis. Econometric Theory. 20(3), 597-625. doi:10.1017/S0266466604203073, http://dx.doi.org/10.1017/S0266466604203073

Ra, H.R. (2006). Opportunity cost effects on the demand for international reserves in the high reserve era. University of Hawaii at Manoa Job Market Paper.

World Bank (2005). Global Development Finance. Washington, D.C.: World Bank.

World Bank (2007). World Development Indicators. Washington, D.C.: World Bank.

Zhou, Y. (2005). International reserves and fiscal policy in developing countries. California State University Working Paper. 
Table 1. Data and Sources

\begin{tabular}{ll}
\hline Data & Source(s) \\
\hline Consumer price index & $\begin{array}{l}\text { International Financial Statistics (IMF, 2007) } \\
\text { Directorate General of Budget, Accounting, and Statistics, Republic of Taiwan (2008) }\end{array}$ \\
\hline Current account balance & International Financial Statistics (IMF, 2007) \\
& Bank of Japan (1994). \\
\hline Current account balance (as percent of GDP) & World Development Indicators (World Bank, 2007) \\
\hline Exports (line 70..d) & International Financial Statistics (IMF, 2007) \\
Imports, cif (line 71..d) & \\
Total reserves minus gold (line 11.d) & \\
\hline Short-term external debt & Key Indicators of Developing Asian and Pacific Countries (ADB, various issues) \\
\hline GDP & World Development Indicators (World Bank, 2007) \\
Real GDP per capita & Groningen Growth and Development Center and the Conference Board (2007) \\
\hline
\end{tabular}

Table 2. Results of Panel Unit Root

\begin{tabular}{|c|c|c|c|c|c|c|c|c|}
\hline \multicolumn{9}{|c|}{ Panel A: East Asia } \\
\hline & \multicolumn{4}{|c|}{ Constant } & \multicolumn{4}{|c|}{ Constant and trend } \\
\hline \multirow[b]{2}{*}{ Variable } & \multicolumn{2}{|c|}{ IPS } & \multicolumn{2}{|c|}{ LLC } & \multicolumn{2}{|c|}{ IPS } & \multicolumn{2}{|c|}{ LLC } \\
\hline & Level & $\begin{array}{l}\text { First } \\
\text { Difference }\end{array}$ & Level & $\begin{array}{l}\text { First } \\
\text { Difference }\end{array}$ & Level & $\begin{array}{l}\text { First } \\
\text { Difference }\end{array}$ & Level & $\begin{array}{l}\text { First } \\
\text { Difference }\end{array}$ \\
\hline $\ln R$ & 0.48 & $-9.84 * * *$ & -0.51 & $-9.38 * * *$ & 0.20 & $-8.38 * * *$ & -0.18 & $-5.79 * * *$ \\
\hline $\operatorname{lnYC}$ & 1.04 & $-8.59 * * *$ & -0.42 & $-9.23 * * *$ & -1.22 & $-7.77 * * *$ & 1.42 & $-7.81 * * *$ \\
\hline $\ln$ PIM & 0.05 & $-16.22 * * *$ & 0.55 & $-17.67 * * *$ & -0.17 & $-14.00 * * *$ & 2.51 & $-14.94 * * *$ \\
\hline $\operatorname{lnXPV}$ & -0.44 & $-14.362 * * *$ & 0.99 & $-13.72 * * *$ & -0.21 & $-11.65 * * *$ & 6.53 & $-8.99 * * *$ \\
\hline $\operatorname{lnCA}$ & -0.41 & $-13.84 * * *$ & 1.19 & $-8.03 * * *$ & -0.63 & $-11.11 * * *$ & 2.88 & $-3.51 * * *$ \\
\hline $\operatorname{lnSTD}$ & 0.88 & $-11.48 * * *$ & 84.46 & $-13.24 * * *$ & -0.36 & $-10.66 * * *$ & -0.87 & $-12.35 * * *$ \\
\hline \multicolumn{9}{|c|}{ Panel B: ASEAN5 } \\
\hline \multicolumn{5}{|c|}{ Constant } & \multicolumn{4}{|c|}{ Constant and trend } \\
\hline & \multicolumn{2}{|c|}{ IPS } & \multicolumn{2}{|c|}{ LLC } & \multicolumn{2}{|c|}{ IPS } & \multicolumn{2}{|c|}{ LLC } \\
\hline Variable & Level & $\begin{array}{l}\text { First } \\
\text { Difference }\end{array}$ & Level & $\begin{array}{l}\text { First } \\
\text { Difference }\end{array}$ & Level & $\begin{array}{l}\text { First } \\
\text { Difference }\end{array}$ & Level & $\begin{array}{l}\text { First } \\
\text { Difference }\end{array}$ \\
\hline $\ln R$ & 0.86 & $-8.30 * * *$ & -0.17 & $-9.39 * * *$ & -1.17 & $-7.62 * * *$ & -0.05 & $-6.81 * * *$ \\
\hline $\ln Y C$ & 0.73 & $-6.75 * * *$ & $-1.93 * *$ & $-7.98^{* * *}$ & 0.16 & $-5.82 * * *$ & -0.12 & $-7.07 * * *$ \\
\hline $\ln P I M$ & 0.48 & $-13.79 * * *$ & -0.13 & $-15.05 * * *$ & -0.41 & $-11.83 * * *$ & 0.21 & $-12.56^{* * *}$ \\
\hline $\ln X P V$ & 0.52 & $-10.42 * * *$ & 2.03 & $-9.68 * * *$ & 0.17 & $-9.37 * * *$ & 6.09 & $-8.18 * * *$ \\
\hline $\operatorname{lnCA}$ & -1.12 & $-9.21 * * *$ & 2.94 & $-2.04 * *$ & -0.73 & $-12.48 * * *$ & 11.19 & $-12.44 * * *$ \\
\hline $\operatorname{lnSTD}$ & -1.27 & $-9.85 * * *$ & $-2.11 * *$ & $-12.40 * * *$ & -1.03 & $-9.33 * * *$ & 13.09 & $-11.98 * * *$ \\
\hline \multicolumn{9}{|c|}{ Panel C: Non-ASEAN Countries } \\
\hline \multicolumn{5}{|c|}{ Constant } & \multicolumn{4}{|c|}{ Constant and trend } \\
\hline & \multicolumn{2}{|c|}{ IPS } & \multicolumn{2}{|c|}{ LLC } & \multicolumn{2}{|c|}{ IPS } & \multicolumn{2}{|c|}{ LLC } \\
\hline Variable & Level & $\begin{array}{l}\text { First } \\
\text { Difference }\end{array}$ & Level & $\begin{array}{l}\text { First } \\
\text { Difference }\end{array}$ & Level & $\begin{array}{l}\text { First } \\
\text { Difference }\end{array}$ & Level & $\begin{array}{l}\text { First } \\
\text { Difference }\end{array}$ \\
\hline $\ln R$ & 1.22 & $-5.56 * * *$ & 1.07 & $-3.56 * * *$ & -1.17 & $-6.65 * * *$ & 0.82 & $-5.50 * * *$ \\
\hline $\ln Y C$ & 0.68 & $-5.37 * * *$ & $-1.79 * *$ & $-4.98 * * *$ & -0.02 & $-5.17 * * *$ & 1.21 & $-3.83 * * *$ \\
\hline $\ln$ PIM & -0.34 & $-8.96^{* * *}$ & 1.57 & $-9.40 * * *$ & 0.67 & $-7.81 * * *$ & 3.59 & $-8.28 * * *$ \\
\hline $\ln X P V$ & -1.25 & $-9.90 * * *$ & -0.52 & $-9.80 * * *$ & -0.49 & $-7.01 * * *$ & 11.40 & $-4.47 * * *$ \\
\hline $\operatorname{lnCA}$ & -0.92 & $-10.45^{* * *}$ & 1.539 & $-10.58 * * *$ & -0.99 & $-9.89 * * *$ & $-2.02 * *$ & $-9.78 * * *$ \\
\hline $\operatorname{lnSTD}$ & 1.58 & $-6.30 * * *$ & 75.61 & $-5.87 * * *$ & -1.22 & $-5.69 * * *$ & 7.96 & $-4.99 * * *$ \\
\hline
\end{tabular}

Note: *** and $* *$ indicate significant at $1 \%$ and $5 \%$ levels, respectively. The null hypothesis for both the IPS and LLC tests is that the series is non-stationary. $\operatorname{lnR}$ is the ratio of international reserves to GDP, logged; lnYC is real GDP per capita, logged; lnPIM is average propensity to import (imports/GDP), logged; lnXPV is volatility of real export receipts, logged; lnCA is the ratio of current account balance to GDP, logged; and $\operatorname{lnSTD}$ is the ratio of short term external debt to GDP, logged. 
Table 3. Results of Panel Cointegration Tests

\begin{tabular}{|c|c|c|c|c|}
\hline \multicolumn{5}{|l|}{ Panel A: East Asia } \\
\hline \multirow[b]{2}{*}{ Statistic } & \multicolumn{2}{|c|}{ Without Time Dummies } & \multicolumn{2}{|c|}{ With Time Dummies } \\
\hline & Constant & $\begin{array}{l}\text { Constant } \\
+ \text { Trend }\end{array}$ & Constant & $\begin{array}{l}\text { Constant } \\
+ \text { Trend }\end{array}$ \\
\hline \multicolumn{5}{|l|}{ Within group } \\
\hline Panel v-statistic & -0.23 & 0.09 & -0.16 & -1.12 \\
\hline Panel rho-statistic & 1.09 & 0.41 & -0.06 & 0.53 \\
\hline Panel pp-statistic & -0.59 & $-3.03 * * *$ & $-2.46^{* *}$ & $-2.95 * * *$ \\
\hline Panel adf-statistic & -1.39 & $-2.63 * * *$ & $-2.38 * *$ & $-3.32 * *$ \\
\hline \multicolumn{5}{|l|}{ Between group } \\
\hline Group rho-statistic & 1.62 & 1.18 & 0.90 & 1.46 \\
\hline Group pp-statistic & -0.86 & $-3.72 * * *$ & $-2.34 * *$ & $-2.76^{* * *}$ \\
\hline Group adf-statistic & -1.87 & $-3.52 * * *$ & $-2.45 * *$ & $-3.59 * * *$ \\
\hline \multicolumn{5}{|l|}{ Panel B: ASEAN5 } \\
\hline \multirow[b]{2}{*}{ Statistic } & \multicolumn{2}{|c|}{ Without Time Dummies } & \multicolumn{2}{|c|}{ With Time Dummies } \\
\hline & Constant & $\begin{array}{l}\text { Constant } \\
+ \text { Trend } \\
\end{array}$ & Constant & $\begin{array}{l}\text { Constant } \\
+ \text { Trend } \\
\end{array}$ \\
\hline \multicolumn{5}{|l|}{ Within group } \\
\hline Panel v-statistic & 0.50 & 0.62 & 0.25 & -0.61 \\
\hline Panel rho-statistic & -0.31 & -0.14 & -0.13 & 0.59 \\
\hline Panel pp-statistic & $-2.43 * *$ & $-4.03 * * *$ & $-2.54 * *$ & -1.95 \\
\hline Panel adf-statistic & $-3.16 * * *$ & $-3.74 * * *$ & $-2.60 * * *$ & $-2.22 * *$ \\
\hline \multicolumn{5}{|l|}{ Between group } \\
\hline Group rho-statistic & 0.40 & 0.56 & 0.58 & 1.34 \\
\hline Group pp-statistic & $-2.46 * *$ & $-4.45 * * *$ & -2.63 & -1.79 \\
\hline Group adf-statistic & $-3.64 * * *$ & $-4.14 * * *$ & $-2.76^{* * *}$ & $-2.24 * *$ \\
\hline \multicolumn{5}{|c|}{ Panel C: Non-ASEAN countries } \\
\hline \multirow[b]{2}{*}{ Statistic } & \multicolumn{2}{|c|}{ Without Time Dummies } & \multicolumn{2}{|c|}{ With Time Dummies } \\
\hline & Constant & $\begin{array}{l}\text { Constant } \\
+ \text { Trend } \\
\end{array}$ & Constant & $\begin{array}{l}\text { Constant } \\
+ \text { Trend } \\
\end{array}$ \\
\hline \multicolumn{5}{|l|}{ Within group } \\
\hline Panel v-statistic & -0.50 & -0.07 & 0.42 & -0.12 \\
\hline Panel rho-statistic & 1.51 & 0.52 & -0.50 & -0.58 \\
\hline Panel pp-statistic & 1.36 & -0.59 & $-2.04 * *$ & $-3.19 * * *$ \\
\hline Panel adf-statistic & 1.04 & -0.36 & $-1.81^{*}$ & $-3.04 * * *$ \\
\hline \multicolumn{5}{|l|}{ Between group } \\
\hline Group rho-statistic & 1.66 & 0.85 & 0.12 & 0.10 \\
\hline Group pp-statistic & 1.47 & -0.60 & $-1.94 *$ & $-3.00 * * *$ \\
\hline Group adf-statistic & 1.26 & -0.65 & $-1.70 *$ & $-2.98 * *$ \\
\hline
\end{tabular}

Note: $* * *$ and $* * *$ indicate significant at $10 \%, 5 \%$ and $1 \%$ levels, respectively. Critical values for $10 \%, 5 \%$ and $1 \%$ levels of significance are $1.64,1.96$ and 2.56, respectively. v-statistic has the critical value of 1.64 while the rho-statistic, pp-statistic, and adf-statistic have the critical value of -1.64. The null hypothesis for Pedroni's panel cointegration test is that there is no cointegration. 
Table 4. Results of Panel Group FMOLS

\begin{tabular}{lccc}
\hline Variable & East Asia & ASEAN5 & Non-ASEAN Countries \\
\hline $\ln \mathrm{YC}$ & $0.78^{* * *}$ & $0.79^{* * *}$ & $0.77 * * *$ \\
& $(7.51)$ & $(5.06)$ & $(5.60)$ \\
$\ln \mathrm{PIM}$ & $0.55^{* *}$ & $0.57 * * *$ & 0.53 \\
& $(2.43)$ & $(3.32)$ & $(-0.06)$ \\
$\ln \mathrm{XPV}$ & $0.09 * * *$ & $0.10^{* * *}$ & 0.08 \\
& $(4.00)$ & $(4.63)$ & $(0.81)$ \\
$\operatorname{lnCA}$ & $0.23^{* * *}$ & $0.17 * * *$ & $0.31 * * *$ \\
& $(4.48)$ & $(3.67)$ & $(2.62)$ \\
$\operatorname{lnSTD}$ & 0.00 & $-0.03 * * *$ & $0.04 * * *$ \\
& $(-0.44)$ & $(-3.58)$ & $(3.34)$
\end{tabular}

Note: $* *$ and $* * *$ indicate significant at $5 \%$ and $1 \%$ levels, respectively. The null hypothesis is $\beta_{\mathrm{i}}=0$. Figures in parentheses ( ) are t-statistics. lnGDPC is real GDP per capita, logged; lnPIM is average propensity to import (imports/GDP), logged; lnXPV is volatility of real export receipts, logged; lnCA is the ratio of current account balance to GDP, logged; lnSTD is the ratio of short term external debt to GDP, logged.

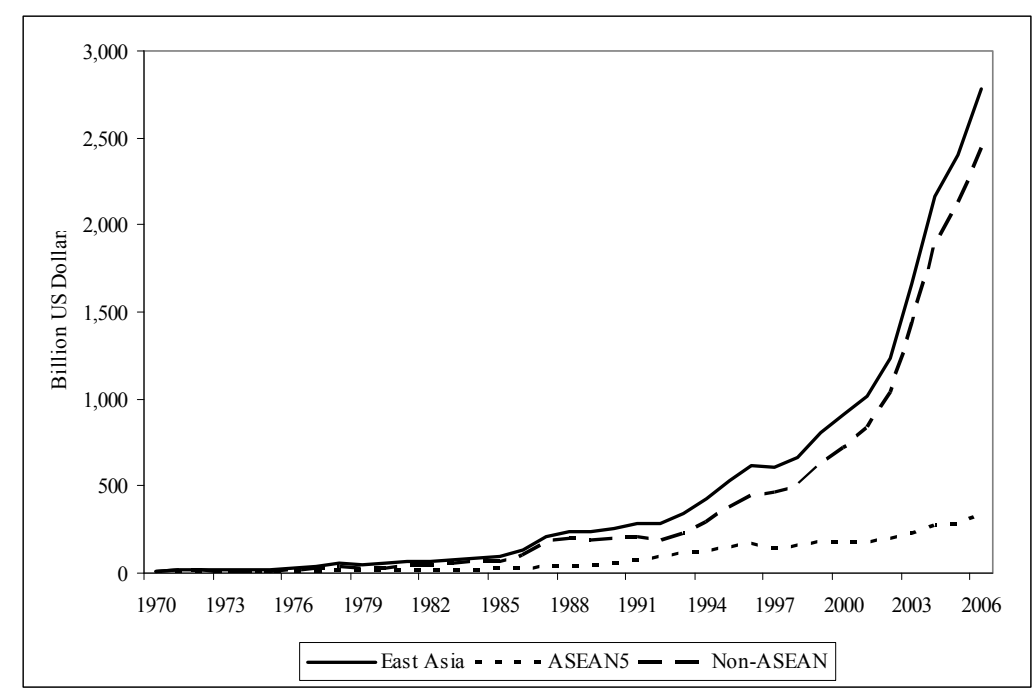

Figure 1. East Asia, ASEAN5, and non-ASEAN Countries: International Reserves (in Billion US dollars) (Source: Lane and Milesi-Ferretti, 2009) 